\title{
Vitalism in early modern medical and philosophical thought
}

\author{
Charles T. Wolfe \\ ERC EarlyModernCosmology (GA 725883) and \\ Cá Foscari University, Venice, Italy \\ ctwolfe1@gmail.com
}

\section{Synonyms}

Organicism

\section{Related Topics}

Hylozoism, Materialism, Panpsychism, Mechanism, Chymistry, Holism

\section{Introduction}

Vitalism is a notoriously deceptive term. It is very often defined as the view, in biology, in early modern medicine and differently, in early modern philosophy, that living beings differ from the rest of the physical universe due to their possessing an additional 'life-force', 'vital principle', 'entelechy', enormon or élan vital. Such definitions most often have an explicit pejorative dimension: vitalism is a primitive or archaic view, that has somehow survived the emergence of modern science (the latter being defined in many different ways, from demystified Cartesian reductionism to experimental medicine, biochemistry or genetics: Cimino and Duchesneau eds. 1997, Normandin and Wolfe eds. 2013). Such dismissive definitions of vitalism are meant to dispense with argument or analysis.

Curiously, the term has gained some popularity in English-language scholarship on early modern philosophy in the past few decades, where it is used without any pejorative dimension, to refer to a kind of 'active matter' view, in which matter is not reducible to the (mechanistic) properties of size, shape and motion, possessing instead some internal dynamism or activity (see e.g. James 1999, Boyle 2018, Borcherding forthcoming). The latter meaning is close to what the Cambridge Platonist Ralph Cudworth termed 'hylozoism', namely the attribution of life, agency or mind to matter, and he implicitly targeted several figures I shall mention here, notably Margaret Cavendish and Francis Glisson, for holding this view. However, one point I shall make in this entry is that when vitalism first appears by name, and as a self-designation, in the Montpellier School (associated with the Faculty of Medicine at the University of Montpellier, in the second half of the eighteenth century; thus vitalisme appears first, followed shortly thereafter by Vitalismus in German, with 'vitalism' appearing in English publications only in the early nineteenth century: Toepfer 2011), it is quite different from both the more 'supernatural' view described above - chiefly espoused by its rather obsessive opponents - and from the more neutral, but also de- 
biologized philosophical view (that of e.g. Cavendish or Conway who are, broadly speaking naturalists). Rather than appealing to a metaphysics of vital force, or of self-organizing matter, this version of vitalism, which I shall refer to as 'medical vitalism', seems to be more of a 'systemic' theory: an attempt to grasp and describe top-level ('organizational', 'organismic', 'holistic') features of living systems (Wolfe 2017, 2019).

In this entry I seek to introduce some periodization in our thinking about early modern (and Enlightenment) vitalism, emphasizing the difference between the seventeenth-century context and that of the following generations - culminating in the ideas of the Montpellier School. This periodization should also function as a kind of taxonomy or at least distinction between some basic types of vitalism. As I discuss in closing, these distinctions can cut across the texts and figures we are dealing with, differently: metaphysical vs. non-metaphysical vitalism, philosophical vs. medical vitalism, medical vs. 'embryological' vitalism, and so on. I examine successively vitalism's Renaissance prehistory, its proliferation as 'vital matter theory' in seventeenth-century England (in authors such as Cavendish, Conway and Glisson, with brief considerations on Harvey and van Helmont), and its mature expression in eighteenth-century Montpellier (notably with Bordeu and Ménuret de Chambaud).

\section{Vitalism: a problem of definition}

With a term like 'vitalism', one could proceed by giving a definition - I would rather suggest a distinction between different forms of vitalism, as I'll discuss below - or one could ask, who is a vitalist?

If we applied the latter method strictly and looked up its usage and who the term is applied to, we would find Aristotle called a vitalist by many authorities (including Pagel and Grmek), for his notion of ensouled matter, and/or his theory of generation. Oddly, Hans Driesch went as far as to call Aristotle "the first exponent of a scientific "vitalism"' (Driesch 1914, 11, 19). To call Aristotle a vitalist because he holds that the soul is life (or, when dealing with the early modern period, to call William Harvey a vitalist because of the idea that 'the blood is life', as I discuss below) seems a very thin, casual use of the term. I would suggest that if one is to apply this term in earnest, one has to provide a careful definition, however stipulative. This is absent when scholars happily call Harvey, Locke, Spinoza, Leibniz, Hume, and Adam Smith vitalists, at which point it becomes impossible to give a clear or strict meaning to the term, other than a vague appeal to some inherent dynamism or vitality (in the mind, in society, in the economy...).

Faced with this kind of vagueness, I suggest that the term 'vitalism' be restricted to theories in which the difference between 'life' and 'non-life' (living matter and non-living matter, living bodies and dead bodies, bodies and machines, biology and physics, etc.) is crucial, however this difference is detailed and laid out. A careful argument for Aristotle's vitalism, however, is given in Connell 2016; interestingly, it makes Aristotle resemble nineteenth- and early twentieth-century anti-reductionist theorists of biological development more than early modern or Enlightenment vitalists. For Aristotle, Connell writes, there is something in the embryo's soul which is “different from the materials, a potential for form or a vitalist principle, which is already present" and can bring about the emergence of complex biological structures (Connell 2016, 211). This vital principle is nonmaterial, and directs development (ibid., 233). I shall return to this question of a 'biological' (actually, embryological) vitalism versus a medical vitalism in the Conclusion.

One source of confusion with the term 'vitalism' is that in earlier centuries (the Renaissance, the earlier early modern period) it often seems to apply to visions of living matter or even the entire universe as alive, whereas in the later part of the period we are concerned with (the later early modern period and the Enlightenment) and beyond, its scope has narrowed, relatively speaking, so that it is now a 
specifically medical (or biomedical) doctrine, no longer concerning the universe or matter in general, but living and dying bodies, sick and healthy bodies.

\section{The pre-history of early modern vitalism}

In the Aeneid, Virgil writes, with Platonic echoes, that "heaven and earth and the watery plains ... a spirit (spiritus) within sustains; in all the limbs mind (mens) moves the mass and mingles with the mighty frame" (cit. in Regier 2014, 7). A bit less than seventeen hundred years later, Margaret Cavendish echoes this vision of a system of planets entirely alive due to its "spirits" (now in the plural):

The Earth, Sun, Moon, the rest of Planets all

Are mov'd by that, we Vital Spirits cal.

And like to Animals, some move more slow,

And other some by quicker motion go.

And as some Creatures by their shapes do flye,

Some swim, some run, some creep, some riseth high

(Cavendish 1655, “Of Matter And Motion,” ch. 57, 24)

In fact, unsurprisingly, Cavendish is different - modern, post-Cartesian - as I shall seek to make clear further on. Yet both Virgil and Cavendish capture quite well the older sense of vitalism as a vision in which life or spirit is present throughout the cosmos, animating all parts of matter. Following Kevin Chang, we should distinguish, then, between cosmic and immanent vitalism. Cosmic vitalism is what Virgil depicts, ultimately, a doctrine in which a "universal spirit" permeates and enlivens "all things in the geocosmos" (Chang 2011, 324). Authors as diverse as Aristotle, Galen, Ficino, Paracelsus and Telesio were invoked in support of this view. In contrast, Chang suggests, immanent vitalism, a post-Renaissance development, "presumed a principle of life that was intrinsic to matter" (ibid., 328). Some Renaissance authors such as Campanella, for whom solar heat confers life to natural bodies, and sensibility is distributed throughout all bodies and serves to preserve life, could be seen as immanent vitalists but that is not an issue to be resolved here. The shift from cosmic to immanent vitalism is an initial narrowing of the vitalist conceptual space, but ultimately, by the early years of the eighteenth century, a further narrowing occurs, which Chang attributes particularly to the German professor of medicine Georg-Ernst Stahl (1659-1734). Afterwards, "vitalists never reclaimed the inorganic world as their territory. The vital principle was forever localized in the organism and vitalism confined to the life sciences" (ibid.).

This entry is primarily devoted to the latter kind of vitalism, particularly in a medical context (understood in an expansive sense to include iatrochemistry, matter theory, and the various metaphysical appropriations and transformations of this "vital matter theory"). But it is important to situate and describe some of the core notions involved in early modern vital matter theory - which is, I will suggest, not quite full-blown vitalism but its matter-theoretic older cousin.

One such core notion, perhaps the core notion, which seems to be omnipresent in Renaissance texts, notably Marsilio Ficino (1433-1499)'s De triplici vita (1489) and Jean Fernel (c. 1497-1558)'s De abditis rerum causis (1548) and Physiologia (1567), was 'vital spirit' or spiritus, a semi-material substance acting as the instrument of the soul. Disturbing the clarity of Chang's cosmic-immanent distinction, there is a sense in which vital spirits cross the boundary between the cosmic and the embodied. After all, spirits functioned as an intermediary between body and soul; as Jonathan Regier has 
noted, they are often described as "straddling the divide between material and immaterial"; "as a carrier of vital heat," they are "both quotidian and divine. . both sublunary and supralunar" (Regier 2014, 6). Differently put, spirits are ontological go-betweens, something that is loudly and vibrantly announced on just about every page of the works of the authors discussed below, notably Glisson, Cavendish and Conway (but not, precisely, eighteenth-century vitalists, who gradually dispense with such notions in a process one might see as a kind of secularization or naturalization).

Spirits in this context, deriving in part from the Stoic pneuma, are material but very fine, and increasingly in authors like Telesio and Glisson, they become a loci of agency. Where Galen distinguished between vital and animal spirits, Bacon treated spirits in his matter theory as volatile substances contained in all natural bodies (Clericuzio 1994, Begley 2016, Rusu 2018). Crucially, the materiality of spirits does not prevent them from having appetites, desires and impulses as basic features - and these 'mind-like' properties traverse the boundary between the material and the immaterial. In the seventeenth-century English 'protovitalist' discussion at least, vital spirits spread vital heat while animal spirits are a further refined or more rarefied stage of spirits, filtered in the brain and responsible for motion and perception (the original distinction was actually a tripartition between natural, vital and animal spirits.) The story is rendered more complicated by the fact that this apparently 'materialist' story of different types of rarefaction, yielding different chemical states, some of which are termed 'vital spirits', is also dependent, in the Helmontian context, on divine illumination (with well-known images of life as a 'spark', 'little flame', 'breath' etc.).

How vital spirits function, how they related to atoms, and to different and rapidly evolving chemical concepts, is not at all monolithic, and is outside the scope of this entry (further discussion would focus on key notions such as digestion and fermentation INSERT CROSS REFERENCE TO ENTRY FERMENTATION). I can only emphasize that overall, vital spirits are material, or better, are a key case of how the degree of rarefaction of matter makes a difference to its degree of spirituality, active power or agency, sometimes presented under the heading of 'subtle matter' (very prominent in natural philosophers such as Thomas Willis), linked to images like 'subtle wind' or 'subtle spirit', 'very fine matter', fire or flame, all of which convey the idea that the soul is composed of a special kind of matter. For Willis, corpuscles of spirit (very active particles) and corpuscles of sulphur have an affinity, and produce a stable chemical compound that provides the foundation of vital processes. Emphasizing subtlety qua spirit(uality), Conway writes: "For all motion wears away and divides a thing and thus makes it subtle and spiritual. In the human body, for example, food and drink are first changed into chyle and then into blood, and afterwards into spirits, which are nothing but blood brought to perfection" (Conway 1996, VIII.5, 61-62). Oftentimes, despite attributing a great deal of agency, of mindedness - basically, of life to matter, these authors spoke out firmly and consistently against a notion of 'brute', 'dull' or 'inert' matter.

Thus Cavendish describes how even wood or stone sense or know: "wood, stone, or metal, acts as wisely as an animal"; lest this seem unbelievable, she adds concrete examples: "Opium will act very wisely in Sleeping," or "Quicksilver or Mercury will act very wisely, as those that have the French disease can best witness" (Cavendish 1664, IV.xxx, 514). Susan James discusses Cavendish's example of rhubarb (taken from van Helmont, she suggests), which "acts wisely in Purging": "How does the rhubarb 'know' when to purge? It possesses an ability to 'see' differences between the bodies it encounters which is analogous to our power of vision, so that it is appropriate to describe its ability as a kind of sensing, which depends on a kind of knowledge" (James 1999, 227). Cavendish takes over the medical notion of spirits but turns it into a metaphysical account of different types of matter (Begley 2016, ch. 2).

In fact, rather than the theme of spirits per se, the crucial idea here is that knowledge or sensation ("sense" is often described in terms of "sensing that," and knowledge is sometimes treated as a 
development of a basic feature called "sense") is basic in matter. One could also think of it in explicitly non-Cartesian terms, as an ontology in which, rather than matter versus mind, there are different kinds of matter, more or less refined, more or less coarse, such that at the more rarefied end of the spectrum, matter takes the form of vital or animal spirits that possess rudiments of agency. Montpellier vitalists in the mid-eighteenth century take up this idea of 'sensation' again as an anti- or actually post-mechanist motif conveying how vital processes have a rudimentary teleology and reactivity.

It should also be remarked that the vitalist thematic is notoriously recalcitrant when it comes to disciplinary identities. It is difficult to distinguish texts and authors here in terms of disciplines, because a natural philosopher like van Helmont, with his notion of archeus, is both steeped in metaphysics and is immediately taken up in discussions of 'Life' by authors like Margaret Cavendish. Similarly, Francis Glisson's medical researches seem to lead him to write a metaphysics of living substance. (A century later, when Albrecht von Haller grudgingly acknowledges Glisson's priority on the concept of organic irritability, he does his best to disqualify him as merely a metaphysician, as opposed to an experimentalist like Haller himself - but a close examination of Haller's writings reveals various appeals to 'living forces' and overall, a thematization of properties such as irritability and sensibility which are ... uniquely vital properties: Giglioni 2008.) Authors can be go-betweens, but so can some theoretical entities like spirits.

Something similar applies to disciplines, in this case medicine, natural philosophy and metaphysics. It is hard to separate a 'philosophical vitalism' from a 'medical vitalism' in many cases. For instance, Cavendish's reading both of Descartes' Passions of the Soul (Begley 2016) and of natural philosophers including William Harvey, influenced her active-matter metaphysics (which in turn influenced natural-philosophical work like that of Nehemiah Grew: Begley 2017). Conversely, Glisson himself is definitely not a metaphysics-free physician. Further, at the heart of medical vitalism proper (in the eighteenth century), we find authors such as Théophile de Bordeu listing amongst the possible hypotheses on the nature of matter, Leibniz's monads as well as Buffon's organic molecules, and reflecting on how "we would need a Descartes or a Leibniz to disentangle what concerns the causes, order, relations, variations, harmony and the laws of the functions of the animal economy" (Bordeu, Recherches anatomiques, § CXXXII, in Bordeu 1818, vol. 1, 208).

\section{Early modern vital matter theories 1: Harvey and van Helmont}

William Harvey (1578-1657) is sometimes termed a vitalist - incorrectly, I find - for a variety of reasons. Sometimes it is his account of generation and appeal to Aristotle (which is, to be sure, 'antireductionist' and specifically anti-atomistic, but that is not a sufficient criterion for vitalism). Other times it is his approach to experiment and favouring unmediated experience (what I've called elsewhere his “embodied empiricism"). To be sure, his identification of the blood's heat with vital spirits from his 1628 De motu cordis onwards, and his focus on the punctum saliens, the "capering point of blood" at the start of life, was influential in the early modern English context in authors like Glisson, Grew and Cavendish. In animals, the heart is a pump for the blood; in the embryo the punctum saliens performs the same function since it acts like a pump. Most lyrically, he makes use of the phrase from Leviticus 17.10-14: "the blood is life," or "For the life of the flesh is in the blood." Harvey actually writes, "vita igitur in sanguine consistit" (in the translation of the period: life "consists in the blood . . . because in it the Life and Soule do first dawn, and last set," Harvey 1651, ex. LI, 303) - a notion he also puts forth in the earlier Prelectiones and in De motu cordis. We could see the claim that 'the blood is life' as compatible with materialism, but in context it was taken in rather the opposite sense, as a demonstration of the 
presence of rudimentary activity at basic levels of matter. In more metaphysical form, this becomes (notably in Glisson), the idea of a primordial activity in Nature. But taken in itself, the claim 'the blood is life' is very general: van Helmont, too, believed that the essence of life was to be found in the blood (a basis for his dismissal of bloodletting), yet what do Harvey and van Helmont have in common?

Jan Baptist van Helmont (1579-1644)'s place in the history of vitalism derives largely from his use of the Paracelsian concept of an archeus, which was viewed as a direct precursor to Georg Ernst Stahl's conception of the soul as governor of the body as early as the eighteenth century (see e.g. von Haller 1774, 697 and for an excellent overview, to which I am indebted here, Demarest forthcoming). Spirits were central in Paracelsian medicine and were reinterpreted in chemical terms by van Helmont; he rejected the traditional tripartition of spirits and reduced them to one, the vital spirit, which he conceived as an alkaline volatile salt. His 1652 Ortus Medicinae contains a detailed account of the chemical process generating the spirit of life. According to van Helmont, the archeus is an internal, seminal efficient cause responsible for both the generation and the government of natural substances (van Helmont 1652, 33-34). This archeus has within itself a kind of knowledge of how it needs to proceed, which is "naturally infused in it by God" (van Helmont 1652, 28). Van Helmont also distinguished between the general archeus, which is responsible for generation, and operates throughout the body, and the archei that the general archeus assigns to a specific organ and that remain in that organ until death (van Helmont 1652: 33). On van Helmont's view, then, the body is governed not just by a general, quasi-intelligent and purposively acting spiritual agent, by also by a host of subsidiary agents of that kind. The archeus also possesses a faculty of imagination, which makes it capable of having passions that can lead to disease and dysfunction in the body (van Helmont 1652, 437-439). Later Montpellier vitalists cited van Helmont enthusiastically.

\section{Early modern vital matter theories 2: Cavendish, Conway and Glisson}

\section{(a) Cavendish}

Margaret Cavendish (1623-1673), Duchess of Newcastle, is perhaps the most striking addition to the canon in early modern philosophy in recent decades. An author of metaphysical treatises, impressionistic forays into philosophy of nature, science fiction (and plays, and poetry), she was also famously a critic of the then-greatly-admired experimental philosophy associated with the Royal Society. As a philosopher she is often compared to Spinoza or Leibniz; in recent decades important work seeks to understand her in her own right, on her own terms (or perhaps via a retranslation of these terms into current concerns, whether certain styles of rational reconstruction in the history of philosophy, or gender studies). As Susan James observed in one of the first important studies of Cavendish's philosophical thought, Cavendish "can be placed among a collection of English vitalists who, to varying degrees, were not persuaded that all natural phenomena are mechanically explicable by appeal to the motions and impacts of inert particles of matter, and who inferred that matter must possess some kind of active or vital power" (James 1999, $219,227)$. Importantly for our purposes, this idiosyncratic vital matter metaphysics was influenced by medical doctrines and concepts of the period - although it is less often a matter of direct influence, appropriation of ideas and citation than a kind of parallel series of developments, as the case with the interest in 'subtle matter' but also in 'spirits' in a variety of medical and philosophical authors in England 
in this period (including Cavendish, Glisson and Conway, all discussed here; see Begley 2016, ch. 2 for more details).

Cavendish is frequently described, less carefully than in James' description above, as a vitalist, a materialist, a vital(ist) materialist or even an 'organicist materialist'. These labels tend to refer to positions she takes such as her anti-mechanism: "pressure and reaction does not make perception" (Cavendish 1664, I.iv, 18). Like Conway whom I discuss below, she is a sharp critic of metaphysical distinctions between mind and matter, activity and passivity, life and non-life, challenging the idea that Nature needs to have Mind or power of activity added to it, and thereby affirming an idea of animate matter: "why should it not be as probable, that God did give matter a self-moving power to her self, as to have made another creature to govern her? For nature is not a babe, or child, to need such a spiritual nurse, to teach her to go, or to move ..." (Cavendish 1664, II.vi, 149; also Cavendish 1666, I.xv, 44 and "Further Observations," ch. XIV, 44). More than an explicit vitalism, this is a clear (and recurrent, in her work) emphasis on self-organization; for instance, she speaks of the soul as "material self-moving Substance" (Cavendish 1666, "Further Observations," ch. XV, 45, emphasis in original).

Cavendish's views on life and matter comprise, summarily, a general insistence on a spectrum or gradation of complexity rather than on a type of dualism, and more specifically, within this monistic sense of greater or lesser complexity of matter/life/spirit, an emphasis on the presence therein of selfknowledge, self-awareness or "self-love," sometimes presented as a definitory feature of life.

The first point can be stated more plainly: matter and spirit are not opposed, but characterized by different degrees of complexity (also given that Nature, as a corporeal substance for Cavendish, has “infinite parts, as well as an infinite body," Cavendish 1664, XXVI.3, 344; this distinction itself is increasingly problematized as she distinguishes between material and immaterial spirits). Like with medical notions of vital or animal spirits, the issue is the degree of rarefaction of matter so that it reaches the status of 'spiritus'. In fact, Cavendish comments on animal spirits that she doesn't hold them to be "the cause of all sense and motion," but they are simply - like all other bodies - somewhere on the spectrum: they are "not so gross" as some bodies, but are parts "of a most pure, refined and rare sort of inanimate matter," which in its commixture with parts of animate matter, is "enlivened by them" and thereby becomes "very subtil and active" (Cavendish 1666, "Further Observations," ch. VIII, 26-27). She elegantly refrains from placing them at the highest degree of almost animate matter, because there [is] no such thing as first and last in nature" (ibid., 27). Cavendish then asks what we might call 'a good question', if she were our colleague: are animal spirits self-moving? And she effectively forces the outcome: if they are (which is the view she favors), it is because nature is self-moving; but if they are not, where does motion come from? And the answer, there too, is Nature as self-moving... (ibid., 29).

As to what matter is, Cavendish revises her views over time, sometimes sounding more mechanismfriendly (or atomistic), sometimes less, and there is by now an industry on the topic in English-language scholarship. I shall simply note that she distinguishes between three types of matter: rational, sensitive, and inanimate (Cavendish 1666, passim, first stated synthetically in the "Argumental Discourse"), which she names the Triumvirate of Nature (Cavendish 1666, ch. I.xxxvii, 190 and "Observations upon the Opinions of Some Ancient Philosophers," 49, also developed in the 1663 edition of the Philosophical and Physical Opinions). These three types, which she relates to notions of animal and vital spirits, are "closely joined and commixed" (or blended) (Cavendish 1664, I.xxx, 99) within each and every piece of matter, such that, no matter how small a part of matter we consider, it is made up of the three kinds of matter. More simply put, in Cavendish's own words, there is no part of nature that is not a "commixture of animate and inanimate matter" (ibid., 98, 99; Cavendish 1666, "To the Reader," n.p.; Boyle 2018 for general discussion). 
The second point sounds more 'vital': "wheresoever is matter, there is life and self-knowledge; nor can a part lose self-knowledge, any more than it can lose life" (Cavendish 1666, "To the Reader," n.p.); note the appeal to higher-level properties: "there is no part of Nature that hath not life and knowledge" (Cavendish 1664, I.xxx, 98, 99), and conversely, the soul is material (albeit "material self-moving substance": Cavendish 1666, "Further Observations," ch. XV, 45). The world is composed just of selfmoving matter and nothing more, but, as in earlier Renaissance animisms, as well as Bacon and Glisson (as Guido Giglioni has studied in a variety of landmark essays), at the basement level of matter we find not just motion but properties usually viewed as 'higher-level', namely, perception and generation (and sometimes appetite). In fact, Cavendish abandoned the previous idea that matter could be made up of infinite living atoms endowed with knowledge, for the reason sometimes known as the 'Achilles problem': agreement and consent (unification) could not arise from a scattered combination of principles of movement, each of them individuated and capable of perception. "The truth is," she argued, "every Atome being single, must be an absolute body by it self, and have an absolute power and knowledg; by which it would become a kind of a Deity; and the concourse of them would rather cause a confusion, then a conformity in Nature because all Atomes, being absolute, they would all be Governours, but none would be governed" (Cavendish 1666, I.xxxi, 142). This shift is apparent in the second edition (1663) of her 1655 Philosophical and Physical Opinions, but is already there earlier, even in her Philosophicall Fancies (1653); she only embraces atomism wholeheartedly in her Poems, and Fancies (1653).

This rather chaotic vision, even if she was criticizing it herself, distressed authors like Ralph Cudworth (1617-1688). In his True Intellectual System of the Universe (1678), Cudworth denounced Cavendish's theory as hylozoistic (giving life and perception to matter), and thus atheistic, without naming her outright but calling her a "bungling well-wisher" to irreligion (Cudworth 1845, I, 204). He also criticized - linking the two - Francis Glisson (discussed below) for what he called the notion of a "commonwealth of percipients," i.e., Nature seen as a chaotic assemblage of myriad particles endowed with appetites and perceptions. As we shall see below when discussing Montpellier vitalism, this apparently fatal problem of how many perceptions could form one unified perception, was in fact embraced as a kind of super-organicism by several eighteenth-century vitalists.

As I noted above, I do not engage here with Cavendish's metaphysics in any detail. Suffice it to say that for her, all of matter possesses some kind of vitality or energy. Wherever there is matter, there is life. Basic motions are actually "self-determined configurational changes within organic matter" (Thell 2015, 11-12). If it is a kind of materialism, it is a very 'enhanced' materialism: "wheresoever is matter, there is life and self-knowledge." But, and this is an important caveat, 'life' does not really mean vitality or organic life for her - leading to an awkward situation as regards her status in early modern vitalism per se. The fact that she helps herself freely to the language and concepts of medicine doesn't mean that like a twentieth-century (philosophical) naturalist, she thinks science (in this case biomedicine) is somehow more fundamental than philosophy: "if Paracelsus was as frequently practised as Galen, it would be as bad as the plague" (Cavendish 1666, "Further Observations," ch. XX, 80). Curiously, some readings of Cavendish treat her anti-mechanistic conception of a living universe as "antipatriarchal" (a view some scholars equate with vitalism!) and/or as embodying a female spirit, sometimes with ecological overtones. A minima, while not taking a position on those interpretive debates, I would note that she is not consistent on matters of gender and that her politics (including as regards marriage) was far from revolutionary. Regardless, her vision of a vitalized universe was radical in its time (and now); even if it is not a direct contribution to early modern vitalism (a view not held by most Cavendish specialists working in early modern philosophy, but that would seem trivially true e.g. in the history of science), it adds to our exploration of the concept of early modern vitalism notably in the sense of clarifying demarcations between kinds of vitalism. 


\section{(b) Conway}

Anne Conway (1631-1679) shared with Margaret Cavendish the situation that due to her gender, she was excluded from formal university studies, but in Conway's case, after studies of ancient languages (including Hebrew) and works by Plato and Plotinus (but also, a close acquaintance with the Kabbalah, Quakerism and some Renaissance natural philosophy, notably Telesio's), she was introduced to Henry More, who became both a mentor and a close friend, writing the (then-unpublished) preface to her work The Principles of the Most Ancient and Modern Philosophy (included in the Conway 1996 edition; I cite the work below by chapter and section numbers, followed by the page number in this edition). This was written in the 1670s up until her death, but only published posthumously in 1692 by Francis Mercury van Helmont (Jan Baptist's son), in Latin translation (the original manuscript was lost, so that subsequent English editions were translations from the Latin).

It is often pointed out that Conway's system resembles a mirror image of that Hobbes: if for Hobbes, all is body, for Conway, all is spirit. Except that it is a more interesting situation, in which (a) matter and spirit transform into one another, and (b) matter is itself just 'gross spirit'. Like the world of vital spirits we discussed above, including the notion of subtle matter, but also like Cavendish's gradations of more or less fine matter, Conway has a graduated metaphysics - she calls it "modal" - in which "every body is a spirit, and nothing else, neither differs any thing from spirit, but that it is more dark; therefore by how much the thicker and grosser it is become, so much the more remote it is from the degree of a spirit, so that this distinction is only modal and incremental, not essential or substantial" (Conway 1996, VI.11, 3940). Body and spirit are not substances but different states of refinement or grossness.

One of the implications of this view of bodies and spirits as just different points on a "a sliding scale of being" (Borcherding forthcoming) is that vitality and perception are spread across this scale too: every body, insofar as it is "affected in one way or another," can experience or possess "sense and thought, love, desire, joy and grief' (ibid., VII.1, 41). Disagreeing both with stark materialism à la Hobbes, a Cartesian mechanistic conception of matter, and a more 'spirited' dualism as in her mentor More, Conway, while indeed emphasizing the spiritual (in that sense like the more "God-drunken" reading of Spinoza), nevertheless consistently stresses that it is a matter of degrees of rarefaction of matter, what she calls "subtlety" (ibid., VIII.5, 61). What is spirit, then? Again, like body, it is a certain degree of refinement (rather than thickness or grossness). Conway seems to take the physico-chemical notion of subtle matter (Paracelsian, Telesian, chymiatric but also Newtonian) and turn it into a metaphysical notion. Spirit is simply more subtle matter than body (body is "condensed spirit" while spirit is "body made subtle": Conway 1996, VII.4, 51; VIII.4, 61).

Lest one think that this metaphysics could resolve into a kind of heightened 'motionalism', a kind of microphysics of bodies interacting at different levels of part-and-whole resolution, she emphasizes that Nature is not a giant piece of clockwork, "for truly there are many operations [in nature] that are far more than merely mechanical"; a clock lacks a "vital principle of motion" (ibid., IX.2, 64). "Having life," for Conway, is precisely more than possessing mechanical motions (ibid., VII.4, 51). Life has a sympathetic power (the phrase is not hers), it communicates by "emanation" of its parts which themselves constitute a "most fitting and appropriate medium for receiving and transmitting its vital action" (ibid., IX.9, 70): a sort of basic sensation. Thus, depending on which end one views Conway's system from, one could derive from it, as one can from Cavendish, if not a vitalism per se (unless by this we mean any doctrine in which matter possesses activity, or mindedness, or life, regardless of the nature of life itself), then a peculiarly vital kind of materialism: "truly, there is no body anywhere which does not have motion and consequently life or spirit” (Conway 1996, VII.4, 51). 


\section{(c) Glisson}

We now turn to a fascinating and boundary-straddling figure, the Cambridge anatomist and physician Francis Glisson (1599-1677). His medical and metaphysical treatment of some key themes concerning life and animation in matter, both resembles the ideas of Margaret Cavendish and at times gives the impression that she might have known his work. But, as Guido Giglioni and Justin Begley have noted, it is really their shared engagement with earlier figures such as Harvey and van Helmont which produces this impression.

In 1672, Glisson published a treatise whose long elaborate Latin title, Tractatus de natura substantiae energetica, seu de vita naturae ejusque tribus facultatibus perceptiva, appetitiva, motiva (usually referred to as De vita naturae), can be read as a short declaration of vitalist intentions: "On the Energetic Nature of Substance, or: The Life of Nature and Its Primary Natural Faculties, that is, the Perceptive, the Appetitive and the Motive Faculties." Here, Glisson's aim was unapologetically philosophical. He presented his treatise, resulting from more than twenty years of metaphysical investigations, as a rigorous inquiry into the ultimate causes of life. Glisson stated from the outset that he had found in matter the deep-rooted foundation of life he had been seeking for many years, the radicale vitae fundamentum (Glisson 1672, b2r).

After publishing various significant medical works, such as De rachitide (on rickets) in 1650 and De anatomia hepatis (on the anatomy of the liver) in 1654, Glisson produced this treatise on the 'life of nature', describing life as immanent to matter ("life is the intimate and inseparable essence of matter" and "matter contains within itself the root of life": Glisson 1672, b1 v). Now, it would be easy to dismiss this as a kind of substance metaphysics, as indeed Haller did when he both credited Glisson with the discovery of the property of muscular irritability and excluded him from the history of science proper (Giglioni 2008; Glisson does coin the term irritabilitas); but clearly Glisson reflects on the nature of our organic structure (organizatio), its relation to our sense organs, and how animal spirits are not a sufficient explanation of the features of 'animation' and complex perception which our sense organs display. However, it remains a challenge to integrate this aspect of Glisson into a Scientific Revolution narrative (it is rather a species of matter theory); further, this very immanentism means that the nature of Life is not a problem to be investigated for Glisson (as it must be for all vitalists).

For Glisson, matter as both foundation and activity is the ultimate reality of things insofar it is the most complete actualization of substantia. He coins a Greek term to refer to this idea of self-sufficient and self-productive substance: ßrovoí $\alpha$, living substance. "Matter, no doubt, contains in its power all the forms and, consequently, all the modes of material life as well. Material souls are modes of matter and they variously modify its primeval life" $\left(\mathrm{b} 2^{\mathrm{r}}\right)$. More specifically, life for Glisson means a principle of perception, appetite and self-motion that is internal to matter (cf. Giglioni 2002, 242; Begley 2016). There cannot be any teleological development in nature without knowledge, and this knowledge belongs to matter. "No external force, motion and rest, texture, schematism, organisation, proportion or nexus of parts can provide this kind of principle. Only God can infuse His creatures with this principle in the act of creation" (b2v). Glisson draws on a variety of sources and influences, including a kind of naturalized Aristotelianism, Suarez, Bacon and Harvey, but also on the rich medical-and-metaphysical toolbox offered by Renaissance Galenism, which called attention to the elementary faculties of the living bodies underpinning the universal cycle of vital self-preservation (through the basic operations of recognition, assimilation and discharge). 
Here the Harveyan circulatory framework plays a key role, first in Glisson's anatomy of the digestive organs: liver, stomach and intestine. While working on the liver, he realized that the natural faculties dealing with chylification and sanguification could not be explained simply in Galenic terms (i.e., vital, but not sentient). One could term this a philosophical crisis: what kind of 'sentience' is at work in the nutritive functions of the body? Glisson stopped working on the planned anatomy of the stomach and intestine and was (one imagines) stuck in a meditative loop, for about twenty years - although the appeal to vital spirit is also present in his medical works: "Life cannot consist without a Vital Spirit" (Glisson et al., A Treatise of the Rickets being a diseas common to children, London, 1651, 100, cit. in Begley 2016, 139). Ultimately, Glisson arrives at the property of irritability (a combination of Galenic and Helmontian concepts). That is, for the bodily fibres to possess this distinctive reactive capacity which he described and theorized (and which, in a complex dialectic of irritability and sensibility, became a hallmark of Enlightenment vitalism), the fibres have to be 'archeal' in the sense of van Helmont's archeus (also invoked by Cavendish), i.e., perceptive, as Giglioni has described. Interestingly, instead of being content with this kind of expanded medical (or 'embodied') vision, Glisson extended this vision of irritability and basic perception to all bodies, animate and inanimate, even cadavers, rocks and chairs (the difference between a living body, a corpse, and a rock, respectively is a matter of organizational complexity): it is $\beta$ rovoía all the way down.

\section{Early modern vital matter theories: vitalism or protovitalism?}

As Regier has written aptly, "sixteenth century and many seventeenth century natural philosophers do not adhere to what we call Cartesian dualism. Instead, they think in terms of gradations: certain things are more refined or coarse than others" (Regier 2014, 27). In the Renaissance context, this predominantly takes the form of hylomorphism (Conway's description of body and spirit as relative points on a spectrum could be thought of in terms of matter and form). Historians of philosophy could quarrel until the cows come home about, e.g. the way in which Cavendish has everything made of matter (except, which matter? matter how?) versus Conway treating body as nothing but condensed spirit (but what is spirit?). In that sense one could also produce a series of distinctions between a more material(ist) vitalism (Cavendish, Glisson) and a more immaterial(ist) vitalism (Conway, van Helmont). Regardless, early modern 'English' vitalism - which one is tempted to call 'protovitalism' - yields a consistent concept of matter as possessing sensation, perception, knowledge.There is a kind of sense and 'knowing' in Nature, like the rhubarb's 'knowing' how to purge.

Why should one term these views 'protovitalist'? Because the conceptual landscapes described above - particularly in Cavendish and Conway -, while they draw significantly on medical thought (including in the cases of authors like van Helmont or Glisson where it becomes somehow circular, perhaps teaching us an old lesson about how fruitless it is to seek to police a demarcation line between science and metaphysics), seem to be primarily arguments for an enriched or enhanced vision of matter, as animate, as self-moving, although Cavendish and Conway's metaphysics seem to go in opposite directions at this point . This is quite far removed from the actual world of medical, physiological, embryological inquiry into what makes living beings tick - nota bene, such inquiries need not be especially experimental: witness medical vitalism's speculative and fruitful appeal to the beeswarm metaphor.

Granted, it is not Cavendish or Conway's fault that late twentieth-century scholars started calling them 'vitalists'; but to shed light on that issue requires making conceptual assessments in and of their work, not as a mere semantic debate within the scholarship. As I shall suggest in closing, for vitalism to be a relevant or meaningful category, it has to be involved in a genuine tension - not an aporia 
necessarily, but a tension between explanations of life and of 'non-life'; the vitalist must be concerned about how to spell out that distinction (which can be done in many ways). But to declare that the entire cosmos is alive, or that humans can become rocks, which can become leaves, or air, is precisely not to address a tension or problem - in that sense, full-fledged vitalism is necessarily post-Cartesian. Differently put, it requires (although is not identical with) a reaction against the seventeenth-century prestige of iatromechanism, a reaction that is perhaps most striking in the case of Stahl, to whom I now turn.

\section{Life, chemistry and the soul: Stahl}

There is a great deal of shifting ground in early modern chemistry/chymistry, including as concerns life. While earlier iatrochemical concepts provide some of the basis for thinking in terms of animate matter, 'seeds' in matter, corpuscles, etc., by the early eighteenth century chemistry seems to be almost entirely devoted to the organic realm, as if the entire science was concerned with mixts, digestion, assimilation and the transformation of merely inert material assemblages into genuinely organic matter. This is on full display in the entries written for the Encyclopédie by the post-Stahlian chemist GabrielFrançois Venel, e.g. "Chymie," "Chaleur," "Digestion" and "Mixte," which emphasize the chemical transformations of the substances involved in the digestive process. Earlier, Boissier de Sauvages had affirmed that there are overall physical laws but within the organism, these produce processes of fermentation and putrefaction which seem to be restricted to living beings. Even works which are mistakenly taken to have a 'mechanist' flavour, like La Mettrie's L'Homme-Machine (1748), have a noticeably 'organismic' perspective and a chemically enhanced matter theory which would have made Descartes or Hobbes blush: "The body is but a watch, whose watchmaker is the new chyle. Nature's first care, when the chyle enters the blood, is to excite in it a kind of fever which the chemists, who dream only of retorts, must have taken for fermentation. This fever produces a greater filtration of spirits, which mechanically animate the muscles and the heart, as if they had been sent there by order of the will" (La Mettrie 1987, I, 105). But what about Stahl himself?

Georg Ernst Stahl (1659-1734) was a celebrated professor of medicine and chemistry (at Jena, then Halle), and also the private physician to the duke of Saxony-Weimar and, later, to King Friedrich I of Prussia. Stahl is today associated primarily with his championing of the phlogiston theory but his medicotheoretical system (his major work is entitled Theoria medica vera, 1708) is striking for its usage and detailed elaboration of a concept of soul (anima) as both explanatory and causally operative throughout the organism. This system was known as animism, and while several Stahlians (both chemists and professors of medicine) were active in France, including in Montpellier, like François Boissier de Sauvages, the authors discussed below were more consistently suspicious of Stahl; at least, they would pick and choose amidst his system but were definitely not committed to a notion of soul.

In his Jena years, still convinced by the possibility of Universalmedizin, Stahl gradually became more sceptical of alchemy, although his phlogiston theory was nonetheless influenced by Paracelsus' tria prima doctrine (via the combustion theory of Johann Joachim Becher). In the Theoria medica vera Stahl reverses Harvey's speculation that blood is the source of life, claiming that anima is responsible for maintaining blood circulation in order (Bauer 2016, 70). This animism - perhaps closer to the maximalist vision of vitalism favoured by its critics - underpins Stahl's status as an early medical homeopath: he assumed that the body, animated by the soul, could be self-healing. Yet Stahl was at least as much a vitalist in the more specific sense that, through anima, he emphasised the distinction between living beings, which possess it, and non-living matter, which does not. 
In early modern discussions of the nature, function and operation of organic bodies (animal or human), including comparisons of these with machines, both real and imagined, it is extremely rare to find distinctions between the two being made on the basis of ontological claims about 'Life' itself or the nature of the frontier separating the living from the non-living, animate matter from inanimate matter. Life itself is not dividing point. A key moment when it does become ontologically controversial, yielding one of the key traits of 'actual' vitalism, is Stahl's debate with Leibniz, primarily on the difference between mechanism and organism, published after Leibniz's death by Stahl as Negotium otiosum (1720; translated in Duchesneau \& Smith 2016). Both Leibniz and Stahl concurred on the specificity of the organism, but Stahl insisted on the centrality of the soul in vital processes: "I protest here against that sentence that absolutely excludes the soul from assuming any power, in any manner or respect, at any place, on vital motions . . . the appetites of the soul are the authors of vital motions" (Stahl, Enodation XX, in Duchesneau \& Smith 2016, 149).

These views were very influential - and hotly debated - in the next decades in what came to be known as Montpellier vitalism (to the extent that various nineteenth-century histories of medicine deliberately conflate the two, but this is a mistake).

\section{Montpellier vitalism}

Who are the Montpellier vitalists? A group of physicians and professors of medicine associated with the Montpellier Faculty of Medicine, in the second half of the eighteenth century, including notably Théophile de Bordeu (1722-1776), who also appears as a fictional character in Diderot's Rêve de D’Alembert), Jean-Joseph Ménuret de Chambaud (1739-1815), Louis de La Caze (1703-1765), François Boissier de Sauvages de la Croix (known as Sauvages: 1706-1767), Henri Fouquet (1727-1806), PaulJoseph Barthez (1734-1806). Ironically, the least-known of these figures, Ménuret, is probably the most original and important when it comes to vitalist theorizing proper, and wrote many major medical entries in Diderot and D'Alembert's Encyclopédie that have only recently been credited to him (on the importance of Ménuret: Rey 2000, Wolfe 2017 and 2019, Wolfe and Terada 2008). Historical studies of this movement and of eighteenth-century medicine overall often stress the opposition between the vitalism of the Montpellier School and the clinical, experimental and thus 'reduction-friendly' approach of the Paris School (Rey 2000, Williams 2003), although some of this opposition was rhetorical, living a kind of autonomous life in the various polemical pamphlets published especially in the waning decades of the Montpellier School, and there were Paris vitalists just as much as there were Montpellier thinkers who, as I'll describe below, were not frontally opposed to mechanism.

The term 'vitalist' is self-applied by the late 1790 s, by Charles-Louis Dumas, the Dean of the Montpellier medical faculty in the early nineteenth century, although recent research has pointed to usage of the term some decades earlier (Toepfer 2011). When the Montpellier authors first spoke of 'vitalism' and 'vitalists', they observed that the term was synonymous with 'sensibilist': e.g., when reflecting on the past vitalist movement in the early nineteenth century, Henri Fouquet stated that the terms amounted to the same thing - "the doctrine of sensibility is the same as that of vitalism," since "whatever is sensitive is vital" (Fouquet 1803, 78). Haller had famously proposed an experimentally founded (and elegantly articulated) distinction between irritability and sensibility, the first a basic property, and the second requiring a relation to what he calls 'the soul', i.e., sentience, but the Montpellier vitalists rejected the distinction in the name of a kind of 'monism of sensibility', not unlike what we encountered in Cavendish, Conway and Glisson, except framed exclusively in medico-physiological terms. Irritability is just a mode of a more general and primary property, sensibility; the latter is now presented as the primary 
and general property of living beings (tantamount to life, as Fouquet says), so that the distinction between irritability and sensibility is jettisoned.

Montpellier vitalism, like any such movement, was a crossroads of influences, interests, discursive tendencies and regularities. Its proponents were not shy about making programmatic statements (Bordeu's 22,000-word entry "Crise" and Ménuret's 8000-word entry "Oeconomie Animale," in the Encyclopédie, are top-quality instances thereof), which we must not always take at face value. For instance, Barthez's vitalism, put forth in the waning decades of the movement, is more aggressively spiritualist and holist, while that of the abovementioned authors is mechanism-friendly, at times materialism-friendly, and more committed overall to a structural and functional vision of life than to reactive attacks on mechanism. Indeed, they frequently seek to map out a medico-theoretical terrain for vitalism which will be free of the excesses of both mechanism (reducing the living body to a set of inanimate parts, thereby also missing the 'whole-person' dimension of disease) and animism (explaining all vital processes by the soul, and thereby abandoning the naturalistic dimension of explanation). I term this a structural theory, not least because Ménuret himself, criticizing seventeenth-century iatromechanism, wrote that the latter "did not even pay attention to the organic structure of the human body which is the source of its main properties" (“Economie Animale," Enc. XI, 364b, emphasis mine).

I shall summarily present some key traits of Montpellier vitalism, reflecting the context of a publication focusing on the interrelation between philosophy and the sciences. These are: (a) its invocation of a Hippocratic tradition; (b) its brand of holism, i.e., the idea that the life of an individual, is the combination of many interacting micro- 'lives' (organs treated as individual lives); (c) this kind of holism is - surprisingly perhaps - mechanism- and (d) materialism-friendly, at least often; it is at times skeptical and does not posit metaphysically specific vital forces. In the next section, I briefly comment on the relation between vitalism and emergent biology.

\section{(a) Hippocratism}

The montpelliérains frequently praise Hippocrates (sometimes opposed to Galen): "Hippocrates was the first and best of the observer physicians" (Ménuret, "Observation," Enc. IX, 316a). This expresses a more general tension they emphasized, between the observational tradition of 'expectant' medicine, of which Hippocrates was the founder, and the more experimental, clinical tradition of interventionist, vivisectionist medicine. The former emphasizes observations and the latter, dissection, analysis, and other disruptive techniques. Now, this privileging of an observer attitude is of course a conceptual construct: it is not self-evident or transparent. An interesting feature is that the Hippocratically inspired physician or médecin-philosophe observes, studies regularities or dysfunctions (fevers and other crises), but does not posit 'vital principles' (metaphysical vitalism) or 'atomic principles' (mechanistic atomism). And this attention paid to regularities or otherwise systemic features of the organism is, of course, a kind of holism. In Bordeu's article "Crise," he returns to an idea he had suggested in his major work, the 1751 Recherches anatomiques, that it is important to try and correlate the medical phenomena observed in the body at a given time with the workings of specific organs, that is, to seek to correlate (organ) structure and function temporally rather than just spatially (Enc. IV, 488). Overall this reflects what nineteenth-century commentators referred to as the "naturalism" of Montpellier vitalism, by which they meant the Hippocratic appeal to natura medicatrix, Nature as the healer.

Now, this is by no means a "return to Hippocrates"; it is a modern reaction to other competing modern medical doctrines. Ménuret speaks quite revealingly of medicine as being "on the verge of a great revolution," in the article "Observation" (the date of composition of these entries is not known exactly - 
the volumes comprising letters A through G appeared between 1751 and 1757, and after the censorship was removed, all subsequent volumes starting at $\mathrm{H}$, thus including "Observation," appeared in 1765). Curiously, this revolution involved a "revival" of "the medicine of Hippocrates, the true observational medicine" (Enc. XI, 316b). As one might expect, a revived Hippocratic medicine will emphasize circular rather than linear causality (the term often used was the "circle of action"), and thereby, the systemic features of the living body (notably 'sensibility', i.e. 'sensitivity'), in language stressing interrelation, such as 'cohesion', 'conspiration', 'consensus' and 'sympathy'; these features are metaphorically captured in the metaphor of the beeswarm (the organism is composed, not of organs considered as mere parts, but as 'little lives', independent lives which nevertheless, in relations of conspiration and sympathy, "concur" in support of the life of the animal as a whole). It is thus a kind of holism.

\section{(b) Holism}

Holism and vitalism are in fact sometimes used almost interchangeably; it is a commonplace that all forms of vitalism must be holistic, given that they reject the mechanistic (typically atomist) decomposition of vital processes into micro-components and thereby down to the level of the basic properties of matter. And some of this is quite present in the Montpellier vitalists. But curiously, they very rarely do so in terms of 'top-down causation', that is, in terms of a higher-level Self or 'controller' animating matter. That is precisely what they reproach Stahl in particular and animism in general for.

How is it that a particular arrangement of parts differentiates a dead body from a living body? The difference lies not merely in the arrangement, but in the very nature of the parts: the vitalist will argue that individual organs, or even fibres, are not merely 'masses' or 'aggregates' but lives:

The body should only be considered as an infinite assemblage of small, identical bodies, similarly alive and animated, each possessing a life, an action, a sensibility - [i.e.] both a specific, particular interaction and movement, and a common, overall life and sensibility. All parts contribute in their own way to the life of the entire body, and as such they reciprocally correspond to and influence one another (Ménuret, "Pouls," Enc. XIII, 240a).

It's a bit like a superorganism: the organism is composed of lots of smaller organisms (with the caveat that, unlike the more embryology-centred vitalism of the early nineteenth century, but also Hans Driesch's in the early twentieth century - see Normandin and Wolfe eds. 2013 - this vitalism does not focus on vital minima at the micro-level, but, reflecting its medical provenance, on human and animal organisms of a larger size). Although by the later decades of the eighteenth century, some Montpellier authors seek to push this 'superorganismic' view of the individual's 'life' as composed of many smaller 'lives', further down the scale: "the life of each organ of the animated body is not a mere unitary life (vie simple) but in truth, the product of as many particular lives as there are living molecules entering into the composition of this organ" (Grimaud 1776, 12). This 'nested individuality' view (a term used recently to describe Leibniz's monadology) is more radical than earlier comparable ideas like Nehemiah Grew's description of animals as made up of so many (living) vegetables (Begley 2017, 499).

\section{(c) Mechanism}

This sounds quite squarely antimechanistic and indeed many of these authors do sometimes demand, like Ménuret, that "we cease to consider the human or animal body as the mechanists and Boerhaavians do, namely, as a crude machine in which all actions and parts are independent of one another" ("Pouls," Enc. XIII, 240a). Yet if we actually examine their writings, notably their discussion of the animal economy, we find an almost shockingly 'thick' presence of mechanistic language and 
explanations, although it is most often an 'expanded', 'enhanced', 'hybridized' kind of mechanism (Wolfe forthcoming). Consider this passage of Ménuret's, where he speaks of the "human machine," its springs, motions, resistance and pressure:

What is man? Or to avoid any misunderstanding ... what is the human machine? It appears at first sight to be a harmonious composite of various springs, each of which is impelled by its own motion but (which) all concur in the general motion; a general property especially restricted to organic composites, known as irritability and sensibility spreads through all springs, animates them, vivifies them and excites their motions. But, modified in each organ, it infinitely varies their actions and motions: it leads the various springs to tighten against one another, to resist, to press, act and mutually influence one another. This reciprocal commixture sustains motions, no action without reaction. From this continuous antagonism of actions, life and health result (Ménuret, "Spasme," Enc. XV, 435b).

Of course, if we do not focus solely on the mechanistic language, various other conceptual 'performances' here stand out. For one, the mechanistic language seamlessly incorporates specifically organic (i.e. 'vital') properties like irritability and sensibility. Further, all of this enhanced mechanistic interaction of living parts yields higher-level properties such as "life and health," via chemical reactions: "no action without reaction." Indeed, chemistry/chymistry plays an enormous role in all of these texts: it is a battleground (as it is in Stahl) in relation to earlier chimiatric theories, as the Montpellier vitalists are in a real sense "post-mechanists" inasmuch as they seek to include the explanatory power of mechanism, but also, a tremendous ontological resource (both in the older sense of a vital chemistry and the newer sense that, e.g. 'hormonal' secretory processes simply can't be adequately modelled mechanistically). Striking evidence of the latter is Gabriel-François Venel's article "Chymie" in the Encyclopédie, yet another self-contained manifesto at 35,000 words: if we took Venel as our source for the science of chemistry in the mid-eighteenth century, we would think all chemistry was devoted to the problem of life...As Andrault has observed judiciously, "there is often a greater proximity, in discussions of vital phenomena, between two figures who are meant to stand for vitalism and mechanism in a given period, than between two 'vitalists' at different times" (Andrault 2013, 141).

Vitalist models in this context, if they are less overtly opposed to mechanistic models than the scholarship recurrently tells us, cannot be reduced to them either. As I've suggested above, their focus in the case of Montpellier vitalism - is strongly structural. When the vitalists protest that the iatromechanist picture of the body leaves out its functional properties, and its dynamic character (in the sense, often expressed as an opposition between "physiology" and "anatomy," that the living body has, not just a teleological dimension but a temporal dimension which a strictly anatomical perspective cannot grasp), they often use the language of "organic structure." A code-word for this is "animal economy," defined in the entry of that title in the Encyclopédie as "the order, mechanism and set of functions that sustain life" (Enc. XI, 362a).

Additionally, this kind of vitalism frowns on the invocation of vital forces or principles as playing a causal role in the material, physical world. Either because, from the medical standpoint, such foundational questions seem out of place (as Bordeu argues elegantly when it comes to taking a stand on the nature of the vital force), or because at bottom, and contrary to the commonplaces one reads, most of the more original Montpellier vitalists were ... materialists in sheep's clothing. I now turn to this aspect.

\section{(d) Skeptical and materialist vitalism}


As I've noted earlier, so many studies, reference works, and casual or serious commentary on vitalism treat it as de facto a supernaturalist view, or at least, a view in which some vital entity is hypostatized and placed above or separate from the rest of the physical universe (raising all sorts of difficulties in terms of causality). It is thus surprising, and one wishes all those scholars and commentators would sit up and take notice, that so much of the more original content in Montpellier vitalism runs directly counter to this common view.

When, in his major work, the 1751 Recherches anatomiques sur la position et la fonction des glandes, Bordeu discusses Stahl's notion of anima as a possible candidate for the source of intentional behavior but also, more broadly, self-preserving behavior, he notes that he "will discuss Stahl's hypothesis elsewhere," but specifies that Stahl "claimed that the soul directed everything in the animal body" (Bordeu, Recherches anatomiques, § CVIII, in Bordeu 1818, vol. 1, 163). After a diplomatic remark that is meant to convey some degree of ontological neutrality ("whatever the case may be"), Bordeu goes on more affirmatively: "all living parts are directed by an ever-vigilant self-preserving force" (ibid.) - here one might think, there is the vitalist appeal to a mysterious vital force! But significantly, he goes on in rather deflationary (or at least agnostic) tones: "does this force belong, in certain respects, to the essence of a part of matter, or is it a necessary attribute of its combinations? [...I] can only suggest a way of conceiving things, metaphorical expressions, comparisons" (ibid.). Indeed, earlier in the same passage he had asked that the reader allow him to use metaphors, for "it is difficult . . to explain oneself, as to the force which so carefully directs a thousand singular motions in the human body and its parts; what terms should we use to describe them?" (ibid.) To be clear, there is something specific ('vital') about the processes and interrelations in the living body, but Bordeu - a prominent figure of the Montpellier school - is reluctant to personify, hypostatize or otherwise give ontological specificity to this process in terms of a special force or principle.

A related point is made by Barthez, albeit in his more inflated rhetorical style. When, in 1806, he issued the revised second edition of his 1776 Nouveaux éléments de la science de l'homme, Barthez added a chapter with the revealing title, "Skeptical considerations on the nature of the vital principle," and insisted that he always followed an "invincible skepticism" (Barthez 1806, vol. I, 27; Notes, 98, n. 18) or a "reasonable Pyrrhonism" (226) when it came to the vital principle. He only "personified" this principle for ease of argument (107), for "one cannot have a priori knowledge of either Matter or Spirits" (83). When he spoke of the vital principle in the first edition, he did not mean it in the sense of an “independently existing entity" (97, n. 18). Like Haller and other influential figures, Barthez invoked the prestige of Newton and Newtonian methods, including that of postulating an unknown $x$ and studying a variety of complex phenomena in relation to this $x$ (whether gravity, as in the original Newtonian context, or vitality in this case), without giving it specific, experimentally founded empirical content. Indeed, Barthez stated that he was "as indifferent as could be regarding Ontology considered as the science of entities" (96, n. 17). This does not mean there was no such thing as vitality in this view (in which case it would become something of a 'negative vitalism'); rather that, despite the fact that hearts beat, blood flows, and livers metabolize, Montpellier vitalists refuse to ontologize this 'vitality' as a special substance, adopting instead what one might term a systemic view.

So far, skepticism (of a heuristic, descriptively oriented sort) seems to be part of the package. What of another position that typically is also viewed as antithetical to vitalism, namely materialism? I cannot go into detail here (see Wolfe and Terada 2008, Wolfe 2019) but briefly put, these authors do not neglect the specific materiality of the organs, fibres, secretions and sympathetic interrelations that they study. They also frown on explanations of these which locate vitality in immaterial agents such as Stahl's anima. Further, Ménuret happily endorses one of the most classic materialist tenets, the dependence of the mental on the physical (or rather the cerebral): "the movement of the fibres of the brain (in concert with the operations of the soul and consequently with the laws governing its union with the body) determines 
internal sensations, ideas, imagination, judgment and memory” (“Economie Animale,” Enc. XI, 361b), although elsewhere, in his entry on Death in medicine, he admits he is not sure about the role of the brain (Enc. X, 721a), and is similarly of two minds when it comes to the cerebral basis of mental illness (affirmative in "Economie Animale," unsure in "Mort" and "Manie"). Ménuret also states, with materialist echoes, that exact knowledge of the animal economy "sheds a great deal of light on the physical [dimension] of behavior" (“Economie Animale," Enc. XI, 360b), playing on the contrast of physique and moral.

It is surprising to find an anti-materialist bias in both of the major earlier works on Montpellier vitalism (Rey 2000, 137 and Williams 2003, 147); in fact, what is noteworthy about eighteenth-century materialism is that several of its main figures are influenced by vitalism, leading it to characteristically assert the autonomy of biological entities and to reject physico-mechanical explanations as developed in the Scientific Revolution (for further critical remarks on scholarship presenting Montpellier vitalism as "Cartesian dualism," which is sorely mistaken even when it comes to figures like Sauvages who defended a version of Stahlian animism, see Wolfe and Terada 2008, 566f.).

\section{Consequences of vitalism}

If Montpellier vitalism, in addition to being the first self-proclaimed instance thereof, is an intellectual constellation featuring more and less mechanism-friendly, materialism-friendly and at times skeptical variants, it also comprises, curiously enough, a kind of internal critique of metaphysics (one is tempted to say 'self-criticism'). That is, it is not just opponents of vitalism (like Haller, or later Claude Bernard) who seek to force it into a metaphysical corner. That critique is operative in vitalist discourse itself. One could speculate as to whether this is a constitutive trait of biological thought overall, in its recurrent struggles against different kinds of reductionism (which it can then, rather dialectically, embrace until a new, heuristically fruitful anti-reductionist episode comes along).

One consequence which is rarely commented on (see the suggestions in Wolfe 2019) is the relation between vitalism and the emergence of biology as a science, in the later eighteenth century. Indeed, the word 'vitalist' appears at much the same time as does the word 'biology', a fact that has not so far been discussed much, if it all. There are unmistakable signs in the vitalist conceptual edifice of a systematization of fields of inquiry, which in the earlier part of the period examined here would have been called 'animal economy', and which bears real resemblance to what by the 1770 s some Wolffian natural philosophers were beginning to call 'biology'. Thus Barthez insists that the separate classes of animals and plants should be brought together in a common scale of living beings and defines the objects of his planned "science of man" as: "the forces of the Vital Principle in man, their communications or sympathies, their unification into a system, their distinctive modifications in the various temperaments and ages, and their extinction at the time of death" (Barthez 1806, "Discours préliminaire," 33). I am not suggesting that 'biology' was founded fifty years earlier than its official birthdate, in a vitalist context, but that the conceptual space articulated by Enlightenment vitalism plays a role in the conceptual conditions of its emergence.

\section{Conclusion}

Who is a vitalist? When are there vitalists? In seeking to answer these questions, one is confronted with a classic tension, between, on the one hand, the need to clarify and make distinctions, and give some 
genuine content to such terms, whether in accordance with actors' categories or by giving an argument for their use (to say that Adam Smith is a vitalist because he has a 'vital' sense of the economy does not seem like an argument), and on the other hand, the realization that such distinctions could amount to a kind of semantic or doctrinal policing (and a fruitless one at that).

Who and what is a vitalist before it is an actor's category in Montpellier in the 1770s (and more significantly in the decades thereafter, as a self-description of the two previous generations of writings from that school)? My suggested criterion for 'robust' or 'actual' vitalism (less so, precisely, for 'protovitalism') is the following: a vitalist is someone who is actively engaged in exploring the divide between life and non-life, and who often views that divide as crucial, to be defended (whether like Stahl or in a more heuristic way, like the montpelliérains). Whereas thinkers for whom the entire cosmos is alive (or for whom life, mind, and knowledge amount to different ways of saying the same thing) are not concerned with this divide. Indeed, this sense of a divide also applies to the mind-body problem, which in that sense cannot be ancient, as Wallace Matson once wrote - in Connell's phrase, "the post-Cartesian mind/body problem would have been foreign to Aristotle and he could not share our repugnance for vitalism" (Connell 2016, 230). While Connell derives from this a powerful and convincing analysis of Aristotle's vitalism, I would see a different moral: that bona fide vitalism is necessarily post-Cartesian.

The historian of vitalism in early modern and Enlightenment life science would then articulate differences between a specifically medical vitalism and more generation (or embryology)-focused vitalisms; their aims, their concepts and one might say, their ontologies are not the same. The former is more of a 'whole-person' focus (ultimately on the patient, on health and sickness as properties of an individual) while the latter moves to the micro-scale but focuses there on properties like self-organization. The whole-person view also yields original forms of holism (what I described as a focus on structure, including in the image of an organism as a Life composed of many little lives).

All of these distinctions are themselves to be contrasted with a more metaphysical vitalism, like that of Cavendish or Conway. The latter has its own definitional challenges: is Cavendish like Virgil or not? She uses 'spirits' in the plural, which is significant: one could distinguish an older, genuinely cosmic vitalism (in Chang's sense), characterized by universal animation, from a modern, if still metaphysical vitalism characterized by bottom-up animation - both of these being distinct from the Stahlian 'immanent' vitalism, which focuses exclusively on the body itself. To Ralph Cudworth - and to a number of contemporary scholars in Anglophone history of philosophy - what is most relevant in vitalism, whether it is viewed as dangerous or as neutral, is hylozoism. To Stahl and the post-Stahlian thinkers seeking to model systemic properties of the organism, hylozoism and other variants of active/vital matter metaphysics are less relevant - although Diderot flips the situation once he reinvests medical vitalism into a new, materialist metaphysics of a living universe.

One of the ways vitalism remains a tricky category is, is it a metaphysical or a scientific hypothesis? If it is just the latter, then it is easily falsifiable (as in Wöhler's synthesis of urea, which falsifies one variant of vitalism, namely the claim that living things are made solely of organic compounds that are non-interchangeable with non-organic compounds - but it is not fatal to any of the other forms of vitalism; Wolfe 2017). If it is the former, it may continue to serve as a useful heuristic or theoretical impetus in various possible episodes of life-science (Gissis 2014) - or be consigned to a different trajectory, that of a 'philosophy of life'. 


\section{Acknowledgments}

This entry is part of a project that has received funding from the European Union's Horizon 2020

Research and Innovation Programme (GA n. 725883 ERC-EarlyModernCosmology).

\section{Cross-References}

Cavendish

Conway

Diderot

Digestion

Fermentation

Glisson

Grew

Harvey

Iatromechanism

Life as Concept and as Object of Science

Mind/Body

Materialism

Mechanization of Life

Medical Materialism

Newton and the Cambridge Platonists

Senses

\section{References}

Andrault R (2013) Définir le vitalisme. Lectures de Claude Bernard. In: Duchesneau F, Kupiec JJ, Morange M (eds) Claude Bernard et la méthode de la physiologie. Editions Rue d'Ulm, Paris, pp 133-155. Barthez PJ (1806) Nouveaux éléments de la science de l'homme, $2^{\text {nd }}$ edition ( $1^{\text {st }}$ ed. 1779), 2 vols. Goujon \& Brunot, Paris

Bauer AW (2016) Normative Entgrenzung: Themen und Dilemmata der Medizin- und Bioethik in Deutschland. Springer, Dordrecht.

Begley J (2016) Margaret Cavendish: The Last Natural Philosopher, Oxford DPhil.

Begley J (2017) 'The minde is matter moved': Nehemiah Grew on Margaret Cavendish. Int Hist Rev 27(4): 493-514.

Borcherding J (forthcoming) A Most Subtle Matter: The (Im)materialisms of Anne Conway and Margaret Cavendish. In: Farris JR and Goecke BP (eds) Routledge Handbook on Idealism and Immaterialism. Routledge, London

Bordeu T (1818) Euvres complètes, 2 vols. Caille et Ravier, Paris. 
Boyle D (2018) The Well-Ordered Universe: The Philosophy of Margaret Cavendish. Oxford University Press, Oxford.

Cavendish M (1655) Philosophical and Physical Opinions. Martin and Allestrye, London.

Cavendish M (1664) Philosophical Letters: Or, Modest Reflections upon Some Opinions in Natural Philosophy. s.n., London.

Cavendish M (1666) Observations upon Experimental Philosophy. A. Maxwell, London.

Chang K (2011) Alchemy as Studies of Life and Matter: Reconsidering the Place of Vitalism is Early Modern Chymistry. Isis 102(2): 322-329.

Cimino F, Duchesneau F (eds) (1997). Vitalisms From Haller to the Cell Theory. Olschki, Florence.

Clericuzio A (1994) The internal laboratory. The chemical reinterpretation of medical spirits in England (1650-1680). In: Rattansi, P, Clericuzio A (eds), Alchemy and chemistry in the $16^{\text {th }}$ and $17^{\text {th }}$ centuries. Kluwer, Dordrecht, pp 51-83.

Connell S (2016) Aristotle on Female Animals: A Study of the Generation of Animals. Cambridge University Press, Cambridge.

Conway A (1996) The Principles of the Most Ancient and Modern Philosophy [1692], transl. \& ed. Coudert A, Corse T. Cambridge University Press, Cambridge.

Cudworth R (1845) The True Intellectual System Of the Universe [1678], 3 vols. Thomas Tegg, London. Demarest B (forthcoming) Soul, Archeus, and Nature in van Helmont's Medical Naturalism. HOPOS.

Driesch H (1914) The History and Theory of Vitalism (orig. 1905), trans. C. K. Ogden. Macmillan, London

Duchesneau F, Smith JEH (eds. and trans.) (2016) The Leibniz-Stahl Controversy. Yale University Press, New Haven.

Fouquet H (1803) Discours sur la clinique. Izar \& Ricard, Montpellier.

Giglioni G (2002) Francis Glisson's Notion of Confoederatio Naturae in the Context of Hylozoistic Corpuscularianism. Revue d'histoire des sciences 55: 239-262.

Giglioni, G (2008) What Ever Happened to Francis Glisson? Albrecht Haller and the Fate of EighteenthCentury Irritability. Science in Context 21: 465-493.

Gissis S (2014) The continuing vitality of the problématique of vitalism? Studies in History and Philosophy of Biological and Biomedical Sciences 47: 196-200.

Glisson F (1672) Tractatus de natura substantiae energetica, seu de vita naturae, ejusque tribus facultatibus perceptiva, appetitiva, motiva. Flesher, London.

Grimaud JCMG de [published under initials D.G.] (1776) Essai sur l'irritabilité. Bonnet frères, Avignon. Haller A von (1774) Bibliotheca Anatomica (vol. I). Orell, Gessner, Fuessli \& co, Zürich.

Harvey W (1651) Exercitationes de Generatione Animalium. Pulleyn, London James S (1999) The Philosophical Innovations of Margaret Cavendish. British Journal for the History of Philosophy 7(2): 219-244.

La Mettrie JO de (1987) Cuvres philosophiques, ed. F Markovits, 2 vols. Fayard- "Corpus”, Paris. Normandin S, Wolfe CT (eds) (2013) Vitalism and the Scientific Image in Post-Enlightenment Life Science, 1800-2010. Springer, Dordrecht

Regier J (2014) Kepler's Theory of Force and His Medical Sources. Early Science and Medicine 19(1): $1-27$.

Rey R (2000) Naissance et développement du vitalisme en France de la deuxième moitié du XVIII ${ }^{\mathrm{e}}$ siècle à la fin du Premier Empire. Voltaire Foundation, Oxford (originally a PhD dissertation in 3 volumes, University of Paris, 1987) 
Rusu DC (2018) Same Spirit, Different Structure: Francis Bacon on Inanimate and Animate Matter. Early Science and Medicine 23(5-6): 444-458

Thell AM (2015) “[A]s lightly as two thoughts”: Motion, Materialism, and Cavendish's Blazing World. Configurations 23: 1-33

Toepfer G (2011) Vitalismus. In: Toepfer, Historisches Wörterbuch der Biologie. Geschichte und Theorie der biologischen Grundbegriffe, vol. 3, J.B. Metzler, Stuttgart, pp 692-710

Van Helmont JB (1652). Ortus Medicinae, id est, Initia Physicae Inaudita, ed. FM. van Helmont. Elsevier, Amsterdam.

Williams EA (2003) A Cultural History of Medical Vitalism in Enlightenment Montpellier. Ashgate, Aldershot.

Wolfe CT (2017) Models of organic organization in Montpellier vitalism. Early Science and Medicine 22: 229-252

Wolfe CT (2019) La philosophie de la biologie avant la biologie : une histoire du vitalisme. Classiques Garnier, Paris.

Wolfe CT (forthcoming) Expanded mechanism and/or structural vitalism: further thoughts on the animal economy. In Wolfe CT, Pecere P, Clericuzio A (eds) Mechanism, Mind and Life in Early Modern Natural Philosophy. Springer, Cham.

Wolfe CT, Terada M (2008) The Animal Economy as Object and Program in Montpellier Vitalism.

Science in Context 21(4): 537-579. 